\title{
ВИВЧЕННЯ ЕФЕКТИВНОСТІ АНТИМІКРОБНИХ КОНСЕРВАНТІВ ПРИ РОЗРОБЦІ СКЛАДУ БІГЕЛЮ ДЛЯ КОМПЛЕКСНОї ТЕРАПІЇ МАСТОПАТІї
}

\begin{abstract}
Актуальність. 3 огляду на поширеність мастопатії серед жіночого населення, згубні наслідки неправильного та невчасного ії лікування та великої вірогідності появи раку молочної залози розробка лікарських препаратів, що могли б впливати на всі ланки патогенетичних механізмів розвитку, важлива і затребувана. Для розширення асортименту комплексних вітчизняних лікарських препаратів для терапії мастопатії було розроблено склад та обгрунтовано технологію бігелю.

Мета дослідження. Вибір консервантів для відповідності розробленого бігелю вимогам ДФУ до показників мікробіологічної чистоти.

Матеріали та методи. При проведенні досліджень використовували методику оцінки ефективності антимікробних консервантів, наведену в ДФУ 2.0 (Т. 1, п. 5.1.3, с. 773). Усі дослідження виконували в асептичних умовах з використанням ламінарного боксу (кабінет біологічної безпеки AC2-4E1 «Еsco», Індонезія). В якості тестмікроорганізмів використовували Staphylococcus aureus ATCC 6538, Pseudomonas aeruginosa ATCC 9027, Candida albicans ATCC 885-653, Aspergillus brasiliensis ATCC 16404.

Результати та їх обговорення. Проведені дослідження з використанням консервантів з ніпагіном/ніпазолом 0,4/0,1 \% (№ 1), калію сорбатом $0,2 \%$ (№ 2), кислотою сорбіновою 0,1 \% (№ 3), з кислотою бензойною 0,2\% (№ 4) і натрію бензоатом 0,25 \% (№ 5) у складі модельних зразків бігелю показали, що отримані результати для зразків з консервантами ніпагіном/ніпазолом $0,4 / 0,1 \%$, з кислотою сорбіновою 0,1 \% і з кислотою бензойною 0,2 \% повністю відповідають вимогам ДФУ за показником «антимікробна ефективність консервантів» щодо лікарських препаратів для зовнішнього застосування.

Висновки. Результати дослідження зразків з консервантами калію сорбатом 0,2 \% і натрію бензоатом 0,25 \% показало, що вони не відповідають вимогам ДФУ за показником «антимікробна ефективність консервантів» (логарифм зменшення кількості життєздатних клітин бактерій Pseudomonas aeruginosa через 2 доби зберігання інокульованих зразків з консервантом натрію бензоатом 0,25 \% менше 2,0 і не відповідає вимогам ДФУ до лікарських препаратів для зовнішнього застосування; по відношенню до культур грибів Candida albicans i Aspergillus brasiliensis через 14 діб зберігання зразків з консервантами калію сорбатом 0,2% і натрію бензоатом 0,25 \% логарифм зменшення числа життєздатних мікроорганізмів був менше 2,0, що також не відповідає вимогам ДФУ). Серед зразків, що відповідають вимогам ДФУ і $є$ перспективними для подальших робіт зі створення бігелю, а саме зразків з консервантами ніпагін/ніпазол 0,4/0,1% (№ 1), кислота сорбінова 0,1 \% (№ 3), і кислота бензойна 0,2 \% (№ 4). Найбільшу антимікробну ефективність показав зразок з консервантом ніпагін/ ніпазол $0,4 / 0,1 \%$ (№ 1 ).

Ключові слова: мастопатія; бігель; консервант; антимікробна активність
\end{abstract}

\section{S. Zuikina, L. Vyshnevska, 0. Strilets}

National University of Pharmacy of the Ministry of Health of Ukraine

Study of antimicrobial preservatives effectiveness in the development of the bigel composition for complex therapy of mastopathy

Topicality. Given the prevalence of mastopathy among women, the detrimental effects of its improper, untimely treatment and the high probability of breast cancer, the development of drugs that should affect all parts of the pathogenic mechanisms of development is important and in demand. To expand the range of complex domestic drugs for the treatment of mastopathy, the bigel composition and technology has been developed and substantiated.

Aim. To select preservatives for compliance of the developed bigel with the requirements of SPhU by the indicators of microbiological purity.

Materials and methods. Method of evaluating the antimicrobial preservatives effectiveness, given in SPhU 2.0 (Vol. 1, paragraph 5.1.3, p. 773) used in the research. All studies have been performed under aseptic conditions with the use of the laminar box (biosafety cabinet AC2-4E1 "Esco", Indonesia). Staphylococcus aureus ATCC 6538, Pseudomonas aeruginosa ATCC 9027, Candida albicans ATCC 885-653, Aspergillus brasiliensis ATCC 16404 were used as test microorganisms.

Results and discussion. Studies using preservatives nipagin/nipazol 0.4/0.1\% (No 1), potassium sorbate $0.2 \%$ (No 2), with sorbic acid $0.1 \%$ (No 3), with benzoic acid $0.2 \%$ (No 4) and sodium benzoate $0.25 \%$ (No 5) in the model samples of bigel showed the results obtained for samples with preservatives nipagin/nipazol 0.4/0.1\%, with sorbic acid $0.1 \%$ and with benzoic acid $0.2 \%$ fully meet the requirements of SPhU in terms of "antimicrobial efficacy of preservatives" of drugs for external use. 
Conclusions. The results of the study of samples with preservatives potassium sorbate $0.2 \%$ and sodium benzoate $0.25 \%$ showed that they do not meet the requirements of SPhU in terms of "antimicrobial efficacy of preservatives" (the logarithm of reducing the number of viable bacterial cells of Pseudomonas aeruginosa after 2 days of storage of inoculated samples with a preservative sodim benzoate $0.25 \%$ is less than 2.0 and does not meet the requirements of $\mathrm{SPhU}$ for drugs for external use; in relation to the cultures of Candida albicans and Aspergillus brasiliensis fungi after 14 days of storage of samples with preservatives, potassium sorbate $0.2 \%$ and sodium benzoate $0,25 \%$ of the logarithm of reducing the number of viable microorganisms was less than 2.0, which also does not meet the requirements of SPhU). Among the samples that meet the requirements of SPhU and are promising for further work on the creation of a bigel there are samples with the preservatives nipagin/nipazole $0.4 / 0.1 \%$ (No. 1), sorbic acid $0.1 \%$ (No. 3), and benzoic acid $0.2 \%$ (No. 4). The highest antimicrobial efficacy has been shown by the sample with the preservative nipagin/nipazole $0.4 / 0.1 \%$ (No. 1 ).

Key words: mastopathy; bigel; preservative; antimicrobial activity

\section{С. С. Зуйкина, Л. И. Вишневская, О. П. Стрилец}

Национальный фармацевтический университет Министерства здравоохранения Украины

\section{Изучение эффективности антимикробных консервантов при разработке состава бигеля для комплексной терапии мастопатии}

Актуальность. Учитывая распространенность мастопатии среди женского населения, пагубные последствия неправильного, несвоевременного ее лечения и большую вероятность возникновения рака молочной железы, разработка лекарственных препаратов, которые должны влиять на все звенья патогенетических механизмов развития, важна и востребована. Для расширения ассортимента комплексных отечественных лекарственных препаратов для терапии мастопатии был разработан состав и обоснована технология бигеля.

Цель исследования. Выбор консервантов для соответствия разработанного бигеля требованиям ГФУ к показателям микробиологической чистоты.

Материалы и методы. При проведении исследований использовали методику оценки эффективности антимикробных консервантов, приведенную в ГФУ 2.0 (Т. 1, п. 5.1.3, с. 773). Все исследования выполняли в асептических условиях с использованием ламинарного бокса (кабинет биологической безопасности AC2-4E1 «Esco», Индонезия). В качестве тест-микроорганизмов использовали Staphylococcus aureus ATCC 6538, Pseudomonas aeruginosa ATCC 9027, Candida albicans ATCC 885-653, Aspergillus brasiliensis ATCC 16404.

Результаты и их обсуждение. Проведенные исследования с использованием консервантов нипагин/нипазол 0,4/0,1 \% (№ 1), калия сорбат 0,2 \% (№ 2), консервантов с кислотой сорбиновой 0,1 \% (№ 3), с кислотой бензойной 0,2 \% (№ 4) и натрия бензоатом 0,25 \% (№ 5) в составе модельных образцов бигеля показали, что полученные результаты для образцов с консервантами нипагин/нипазол 0,4/0,1%, с кислотой сорбиновой 0,1 \% и с кислотой бензойной 0,2 \% полностью соответствуют требованиям ГФУ по показателю «антимикробная эффективность консервантов» к лекарственным препаратам для наружного применения.

Вывод. Результаты исследования образцов с консервантами калия сорбат 0,2 \% и натрия бензоат 0,25 \% показали, что они не соответствуют требованиям ГФУ по показателю «антимикробная эффективность консервантов» (логарифм уменьшения количества жизнеспособных клеток бактерий Pseudomonas aeruginosa через 2 суток хранения инокулированных образцов с консервантом натрия бензоат 0,25 \% менее 2,0 и не соответствует требованиям ГФУ к лекарственным препаратам для наружного применения; по отношению к культурам грибов Candida albicans и Aspergillus brasiliensis через 14 суток хранения образцов с консервантами сорбат калия 0,2 \% и натрия бензоат 0,25 \% логарифм уменьшения числа жизнеспособных микроорганизмов был менее 2,0, что также не соответствует требованиям ГФУ). Среди образцов, отвечающих требованиям ГФУ и которые являются перспективными для дальнейших работ по созданию бигеля, определены образцы с консервантами нипагин/ нипазол 0,4/0,1 \% (№ 1), сорбиновая кислота 0,1 \% (№ 3) и бензойная кислота 0,2 \% (№ 4). Наибольшую антимикробную эффективность показал образец с консервантом нипагин/нипазол 0,4/0,1% (№ 1 ).

Ключевые слова: мастопатия; бигель; консервант; антимикробная активность

\section{ВСТУП}

3 огляду на поширеність мастопатії серед жіночого населення, згубні наслідки ії неправильного та невчасного лікування та великої вірогідності появи раку молочної залози розробка лікарських препаратів, що мали б впливати на всі ланки патогенетичних механізмів розвитку, важлива і затребувана.

3 метою розширення асортименту комплексних вітчизняних лікарських препаратів для терапії мастопатії було розроблено склад та обгрунтовано технологію бігелю.

До переваг системи бігелів відноситься можливість уведення як гідрофільних, так і ліпофільних субстанцій, забезпечення місцевої дії або трансдермальної доставки лікарського засобу, поліпшення споживацьких властивостей лікарських препаратів. Препарати на основі бігелів мають зволожувальний та охолоджувальний ефекти. Збільшення кількісного вмісту органогелю в складі бігелю приводить до посилення зволожувального ефекту за рахунок більшої здатності системи одночасно до доставки та утримування води [1, 2].

Бігелям притаманні оптимальні параметри розтікання, вища стабільність при кімнатній температурі, здатність корегувати властивості системи, експериментуючи з вмістом фракцій та структурним розподілом кожної з них [3].

Важливим етапом фармацевтичної розробки м'яких лікарських форм $є$ вибір консервантів, що забезпечили б мікробіологічну чистоту лікарського препа- 


\section{ПОКАЗНИКИ БЕЗПЕКИ, КРАЇНИ-ВИРОБНИКА ТА ВАРТОСТІ КОНСЕРВАНТІВ, ЩО ЗАСТОСОВУЮТЬСЯ В ТЕХНОЛОГІЇ М'ЯКИХ ЛІКАРСЬКИХ ФОРМ}

\begin{tabular}{|c|c|c|c|}
\hline Допоміжні речовини - консерванти & Ступінь небезпечності & Країна-виробник & За 1 літр/кг \\
\hline $\begin{array}{l}\text { Ніпагін Метилпарагідроксибензоат (Е 218) } \\
\text { (Метилпарабен, Пара-оксибензойної кислоти } \\
\text { метиловий етер) }\end{array}$ & Низька небезпека & США & 364 грн \\
\hline Ніпазол Пропілпарагідроксибензоат (Е 216) & Висока небезпека & Китай & 320 грн \\
\hline Калію сорбат Е 202 & Дуже низька небезпека & Китай & 188 грн \\
\hline Натрію бензоат Е 211 & Висока небезпека & Китай & 60 грн \\
\hline Пропіленгліколь (Е 1520) & Низька небезпека & Німеччина & 82 грн \\
\hline Кислота лимонна & Дуже низька небезпека & Україна & 45 грн \\
\hline Натрію цитрат & Дуже низька небезпека & & 40 грн \\
\hline Олія апельсинова & Низька небезпека & Бразилія & 400 грн \\
\hline Олія лаванди & Низька небезпека & Німеччина & 1230 грн \\
\hline Е 524 (Гідроксид натрію) (регулятор кислотності) & Низька небезпека & Китай / Росія & 20 грн / 100 грн \\
\hline Декспантенол & Дуже низька небезпека & Німеччина & 500 грн \\
\hline E-219 - Метилпарабену натрієва сіль & Низька небезпека & Бельгія & 346,50 грн \\
\hline Сорбіт (E 420) & Низька небезпека & Німеччина & 85,40 грн \\
\hline Бензалконію хлорид & Висока небезпека & Індія & 113,40 грн \\
\hline Бензилбензоат & Низька небезпека & Німеччина & 263 грн \\
\hline Бутилгідрокситолуол (Е 321) & Середня небезпека & Німеччина & 430 грн \\
\hline
\end{tabular}

рату і стабільність упродовж терміну використання та зберігання, що є показником якості лікарського препарату [4, 5].

\section{МАТЕРІАЛИ ТА МЕТОДИ}

При проведенні досліджень використовували методику оцінки ефективності антимікробних консервантів, наведену в ДФУ 2.0 (Т. 1, п. 5.1.3, с. 773) [6].

Принцип методу полягає у тому, що в зразки готової лікарської форми з різними консервантами і концентраціями, які знаходяться у первинній упаковці, вносять певну кількість тест-мікроорганізмів і зберігають дані зразки при певній температурі (від 20 до $25{ }^{\circ} \mathrm{C}$ ) у захищеному від світла місці. Безпосередньо після інокуляції і через визначені проміжки часу (засоби для зовнішнього застосування - 2, 7, 14 і 28 діб) із інокульованих зразків відбирають проби (звичайно 1,0 г) і визначають число життєздатних мікроорганізмів.

Усі дослідження виконували в асептичних умовах з використанням ламінарного боксу (кабінет біологічної безпеки AC2-4E1 «Еsco», Індонезія).
В якості тест-мікроорганізмів використовували Staphylococcus aureus ATCC 6538, Pseudomonas aeruginosa ATCC 9027, Candida albicans ATCC 885-653, Aspergillus brasiliensis ATCC 16404.

Для дослідження було розроблено 5 модельних зразків бігелю, що містять різні антимікробні консерванти: № 1 - ніпагін/ніпазол 0,4/0,1 \%, № 2 - калію сорбат 0,2 \%, № 3 - кислота сорбінова 0,1 \%, № 4 - кислота бензойна 0,2 \%, № 5 - натрію бензоат 0,25 \%.

\section{РЕЗУЛЬТАТИ ТА ЇХ ОБГОВОРЕННЯ}

Для виявлення найбільш конкурентоспроможних (з високим рівнем антимікробної активності та безпеки, економічно обгрунтованих продуктів вітчизняного виробника) консервантів були проведені дослідження ринку консервантів, що застосовуються в фармацевтичній галузі при розробці м'яких лікарських форм. Результати досліджень за показниками безпеки, країни-виробника та вартості наведені в табл. 1.

За даними табл. 1 щодо консервантів, які застосовуються у складі м'яких лікарських форм, та за результатами досліджень (Половко Н.П., Кухтенко Г.П. та ін.) 


\section{РОСТОВІ ВЛАСТИВОСТІ ПОЖИВНИХ СЕРЕДОВИЩ}

\begin{tabular}{|c|c|c|c|c|}
\hline \multirow{2}{*}{$\begin{array}{c}\text { Тест-штами } \\
\text { мікроорганізмів }\end{array}$} & \multirow[b]{2}{*}{ Поживні середовища } & \multicolumn{2}{|c|}{ Умови культивування } & \multirow[b]{2}{*}{ Висновок } \\
\hline & & температура, ${ }^{\circ} \mathrm{C}$ & $\begin{array}{c}\text { термін } \\
\text { культивування, год }\end{array}$ & \\
\hline $\begin{array}{l}\text { Pseudomonas } \\
\text { aeruginosa ATCC } 9027\end{array}$ & $\begin{array}{l}\text { Соєво-казеїновий } \\
\text { агар }\end{array}$ & $30-35{ }^{\circ} \mathrm{C}$ & $24-72$ & $\begin{array}{l}\text { Морфологія колоній } \\
\text { і клітин типова }\end{array}$ \\
\hline $\begin{array}{l}\text { Aspergillus brasiliensis } \\
\text { ATCC } 16404\end{array}$ & $\begin{array}{l}\text { Сабуро-декстрозний } \\
\text { агар }\end{array}$ & $20-25{ }^{\circ} \mathrm{C}$ & $24-120$ & $\begin{array}{l}\text { Морфологія колоній } \\
\text { і клітин типова }\end{array}$ \\
\hline
\end{tabular}

встановлено, що найбільш затребуваними представниками даної групи допоміжних речовин у фармацевтичній галузі є ніпагін та ніпазол $[7,8]$.

Зважаючи на результати попередніх досліджень, показники вартості та ступінь безпеки, для проведення досліджень було обрано наступні консерванти: комбінація ніпагін/ніпазол, калію сорбат, кислота сорбінова, кислота бензойна, натрію бензоат.

Перед проведенням досліджень проводили досліди на відповідність ростових властивостей поживних середовищ (кількість колоній, що виросли при посіві відповідної кількості мікроорганізмів). Поживні середовища інокулювали малою кількістю тест-штамів мікроорганізмів (10-10² колонієутворюючих одиниць на мл середовища - КУО/мл). Вихідну культуру кожного із зазначених тест-мікроорганізмів пересівали на поверхню густого соєво-казеїнового поживного середовища при вирощуванні бактерій (Staphylococcus aureus, Pseudomonas aeruginosa), при вирощуванні грибів (Candida albicans, Aspergillus brasiliensis) пересівали на густе поживне Сабуро-декстрозне середовище без додавання антибіотиків.

Результати досліджень наведені у табл. 2.

Дані, надані в табл. 2, демонструють, що всі культури мікроорганізмів відповідали таксономічному позначенню штаму, а морфологія колоній при культивуванні на поживних середовищах і морфологія клітин при мікроскопії $€$ типовою, то ж ростові властивості поживних середовищ відповідають вимогам.

Для приготування культур тест-мікроорганізмів робили висіви бактерій на поверхню щільного поживного соєво-казеїнового середовища, у випадку висіву грибів використовували Сабуро-декстрозне поживне середовище без додавання антибіотиків. Культури бактерій Staphylococcus aureus i Pseudomonas aeruginosa інкубували у термостаті ТCO-80 при температурі 30-35 ${ }^{\circ} \mathrm{C}$ впродовж 18-24 год, культуру Candida albicans інкубували при температурі $20-25^{\circ} \mathrm{C}$ впродовж 2-3 діб, культуру Aspergillus brasiliensis - при температурі 20-25 ${ }^{\circ} \mathrm{C}-7$ діб.

Для приготування суспензій бактеріальних культур і культури гриба Candida albicans мікробну масу змивали з поверхні поживного середовища стерильним суспендуючим розчином, що вміщує 9 г/л натрію хлориду Р, переносили у стерильну пробірку і доводили вміст мікроорганізмів до $10^{8}$ клітин у мл. При приготуванні суспензії культури Aspergillus brasiliensis використовували стерильний суспендуючий розчин, який містить 9 г/л натрію хлориду Р і 0,5 г/л полісорбату-80 Р та доводили вміст спор до $10^{8}$ у мл. 3 кожної суспензії відразу після її приготування відбирали пробу і визначали кількість колонієутворюючих одиниць (КУО) у 1 мл кожної суспензії шляхом прямого висіву на чашки Петрі на щільні поживні середовища, які використовували для початкового вирощування тесткультур.

До кожного модельного зразка бігелю, що досліджується, вносили суспензію з вмістом тест-мікроорганізмів з навантаженням $10^{8}$ КУО в 1 мл. У самому зразку мікробне навантаження мало становити від $10^{5}$ КУО/мл до $10^{6}$ КУО/мл.

Критерієм оцінки ефективності антимікробних консервантів було визначення логарифму $(\lg )$ зменшення кількості життєздатних клітин мікроорганізмів за відповідний період зберігання після контамінації зразків. У відповідності до вимог ДФУ в препаратах для зовнішнього використання логарифм зменшення числа життєздатних клітин бактерій через 2 доби повинен складати не менше 2-х, через 7 діб - не менше 3-х, а в подальшому число життєздатних клітин бактерій не повинно збільшуватись. Логарифми зменшення числа життєздатних клітин грибів за 14 діб повинні складати не менше 2-х.

Після інокуляції зразків мікроорганізмами (навантаження $10^{5}$ КУО/мл - $10^{6}$ КУО/мл) їх ретельно перемішували для рівномірного розподілення мікроорганізмів у зразку, з кожного зразка відбирали проби: відразу після обсіменіння та через певні інтервали часу (2 доби, 7, 14 і 28 діб), методом прямого посіву висівали на агаризовані поживні середовища на чашки Петрі для визначення кількості життєздатних мікроорганізмів і розрахунку логарифму зменшення кількості життєздатних мікроорганізмів.

Результати дослідження антимікробної ефективності консервантів у модельних зразках наведені в табл. 3. 


\section{РЕЗУЛЬТАТИ ДОСЛІДЖЕННЯ АНТИМІКРОБНОЇ ЕФЕКТИВНОСТІ КОНСЕРВАНТІВ У МОДЕЛЬНИХ ЗРАЗКАХ}

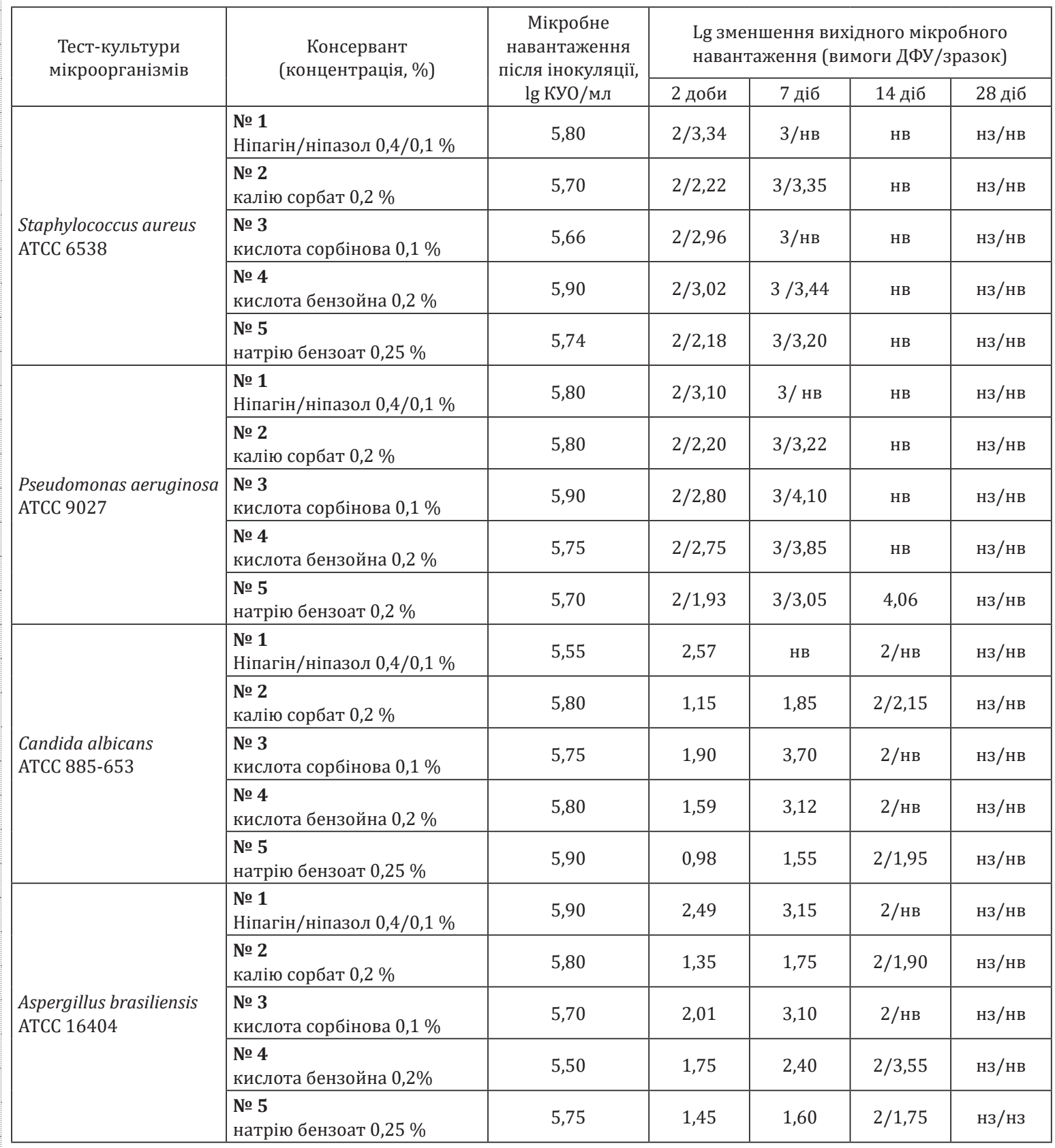

Примітка: нв - мікроорганізми не виявляються; нз - не спостерігається збільшення числа мікроорганізмів.

Результати, наведені у табл. 3, свідчать про те, що через 2 доби зберігання інокульованих зразків з різними консервантами логарифм зменшення числа життєздатних мікроорганізмів бактерій культури Staphylococcus aureus був більше 2,0 для всіх зразків № 1 з ніпагіном/ніпазолом 0,4/0,1\% склав 3,34; для зразків № 2 з калію сорбатом 0,2 \% (№ 2) - 2,22; для зразків № 3 з кислотою сорбіновою 0,1 \% - 2,96, для зразків № 4 з кислотою бензойною 0,2 \% - 3,02, для зразків № 5 з натрію бензоатом 0,1 \% - 2,18. Дані, отримані експериментально по відношенню до культури Staphylococcus aureus, відповідають вимогам ДФУ.

Для культури Pseudomonas aeruginosa (через 2 доби зберігання) логарифм зменшення числа життєздатних мікроорганізмів з консервантом натрію бензоатом 0,25 \% (№ 5) був менше 2,0, а саме 1,97. Для зразків з консервантами з ніпагіном/ніпазолом 0,4/0,1 \% (№ 1), калію сорбатом 0,2 \% (№ 2), 3 кислотою сорбіновою 0,1 \% (№ 3) і з кислотою бензойною 0,2 \% (№ 4) логарифм зменшення числа життє- 
здатних мікроорганізмів бактерій культури Pseudomonas aeruginosa був більше 2,0 і склав 3,10; 2,20; 2,80 і 2,75 відповідно.

На 7-у добу життєздатні клітини мікроорганізмів Staphylococcus aureus у зразках з консервантами 3 ніпагіном/ ніпазолом 0,4/0,1 \% (№ 1 ) і з кислотою сорбіновою 0,1 \% (№ 3) не виділялися, у зразках з консервантом калію сорбатом 0,2 \% (№ 2), з кислотою бензойною 0,2 \% (№ 4) і з натрію бензоатом 0,25 \% (№ 5) логарифм зменшення клітин дорівнював 3,35; 3,44 і 3,20 відповідно (за вимогами ДФу логарифм зменшення повинен бути не менше 3,0 ). В той час як логарифм зменшення числа життєздатних клітин Pseudomonas aeruginosa у зразках з консервантами калію сорбатом 0,2 \% (№ 2), з кислотою сорбіновою 0,1 \% (№ 3), з кислотою бензойною 0,2 \% (№ 4) і натрію бензоатом 0,25 \% (№ 5) дорівнював 3,22; 4,10; 3,85 і 3,05. У зразках з консервантом ніпагіном/ніпазолом 0,4/0,1 \% (№ 1) життєздатні клітини Pseudomonas aeruginosa не виділялися (за вимогами ДФУ логарифм зменшення числа життєздатних мікроорганізмів повинен бути не менше 3,0 ), таким чином, отримані результати відповідають вимогам ДФУ.

На 14-у та 28-у добу інкубації в зразках з консервантами ніпагіном/ніпазолом 0,4/0,1 \% (№ 1), калію сорбатом 0,2 \% (№ 2), 3 кислотою сорбіновою 0,1 \% (№ 3) і з кислотою бензойною 0,2 \% (№ 4) життєздатні мікроорганізми бактерій Staphylococcus aureus i Pseudomonas aeruginosa не були виявлені. У зразках № 5 з натрію бензоатом 0,25 \% на 14 добу логарифм зменшення числа життєздатних клітин Pseudomonas aeruginosa дорівнював 4,06, а життєздатні клітини Staphylococcus aureus не виявлялися, на 28 добу життездатні клітини Pseudomonas aeruginosa i Staphylococcus aureus не виявлялися.

Для клітин грибів Candida albicans i Aspergillus brasiliensis на 14-у добу Lg зменшення числа життездатних клітин у зразках за вимогами ДФУ повинен бути не менше 2,0.

Отримані результати показали, що у зразках з консервантами ніпагіном/ніпазолом 0,4/0,1 \% (№ 1), 3 кислотою сорбіновою 0,1 \% (№ 3) і з кислотою бензойною 0,2 \% (№ 4) життєздатні клітини грибів Candida albicans не були виявлені. У зразках з консервантом калію сорбатом 0,2 \% (№ 2) Lg зменшення числа життездатних клітин Candida albicans склав 2,15, що відповідає вимогам ДФУ. В той же час у зразках з консервантом натрію бензоатом 0,25 \% (№ 5) логарифм зменшення числа життєздатних клітин Candida albicans склав 1,95, що менше за 2,0 і не відповідає вимогам ДФУ.

По відношенню до культури Aspergillus brasiliensis на 14 добу досліджень у зразках з консервантами ніпагіном/ніпазолом 0,4/0,1 \% (№ 1) і з кислотою сорбіновою 0,1 \% (№ 3) життєздатні клітини грибів Aspergillus brasiliensis не були виявлені. У зразках з консер- вантом кислотою бензойною 0,2 \% (№ 4) Lg зменшення числа життєздатних клітин Aspergillus brasiliensis склав 3,55, що відповідає вимогам ДФУ (більше за 2,0). А у зразках з консервантами калію сорбатом 0,2 \% (№ 2) і натрію бензоатом 0,25 \% (№ 5) логарифм зменшення числа життєздатних мікроорганізмів був менше 2,0 і склав 1,90 і 1,75 відповідно, що не відповідає вимогам ДФУ.

На 28-у добу зберігання інокульованих зразків життєздатні клітини грибів Candida albicans і Aspergillus brasiliensis не виділялися зі зразків з консервантами: ніпагіном/ніпазолом 0,4/0,1 \% (№ 1), калію сорбатом $0,2 \%$ (№ 2), з кислотою сорбіновою 0,1 \% (№ 3), з кислотою бензойною 0,2 \%(№ ). У зразках з консервантом натрію бензоатом 0,25 \% (№ 5) на 28 добу зберігання життєздатні клітини грибів Candida albicans не виділялися, кількість життєздатних клітин культури Aspergillus brasiliensis не збільшувалась.

Отже, проведені експерименти з використанням консервантів ніпагіном/ніпазолом 0,4/0,1 \% (№ 1), калію сорбатом 0,2 \% (№ 2), з кислотою сорбіновою 0,1 \% (№ 3), $з$ кислотою бензойною 0,2 \% (№ 4) і натрію бензоатом 0,25 \% (№ 5) у складі модельних зразків бігелю показали, що отримані результати для зразків з консервантами ніпагіном/ніпазолом 0,4/0,1 \%, 3 кислотою сорбіновою 0,1 \% і з кислотою бензойною 0,2 \% повністю відповідають вимогам ДФУ за показником «антимікробна ефективність консервантів» до лікарських препаратів для зовнішнього застосування.

\section{ВИСНОВКИ}

1. Результати дослідження модельних зразків з консервантами калію сорбатом 0,2 \% і натрію бензоатом 0,25 \% показало, що вони не відповідають вимогам ДФУ за показником «антимікробна ефективність консервантів» (логарифм зменшення кількості життєздатних клітин бактерій Pseudomonas aeruginosa через 2 доби зберігання інокульованих зразків з консервантом натрію бензоатом 0,25 \% менше 2,0 і не відповідає вимогам ДФУ до лікарських препаратів для зовнішнього застосування; по відношенню до культур грибів Candida albicans i Aspergillus brasiliensis через 14 діб зберігання зразків 3 консервантами калію сорбатом 0,2 \% і натрію бензоатом 0,25 \% логарифм зменшення числа життєздатних мікроорганізмів був менше 2,0, що також не відповідає вимогам ДФУ).

2. Середзразків, що відповідають вимогам ДФУ і $є$ перспективними для подальшої роботи зі створення бігелю, а саме зразки з консервантами ніпагін / ніпазол 0,4/0,1 \% (№ 1), кислота сорбінова 0,1\% (№ 3), і кислота бензойна 0,2 \% (№ 4). Найбільшу антимікробну ефективність показав зразок 3 консервантом ніпагін/ніпазол 0,4/0,1 \% (№ 1).

Конфлікт інтересів: відсутній. 


\section{ПЕРЕЛІК ВИКОРИСТАНИХ ДЖЕРЕЛ ІНФОРМАЦІЇ}

1. Зуйкіна С. С., Вишневська Л. І. Методологія розробки комбінованих лікарських препаратів на основі лікарської рослинної сировини для лікування мастопатії. Управління, економіка та забезпечення якості в фармації. 2020. № 1 (61) C. 6-13. DOI: https://doi.org/10.24959/ uekj.20.10 (дата звернення: 17.05.2020).

2. Immink J. N., Maris J. J. E., Crassous J. J., Stenhammar O., Schurtenberger P. Reversible formation of thermoresponsive binary particle gels with tunable structural and mechanical properties. ACS Nano. 2019. 13. 3292-3300. DOI: https://doi.org/10.1021/acsnano.8b09139 (Date of access: 01.04.2020).

3. Mazurkeviciute A., Ramanauskiene K., Ivaskiene K. M., Grigonis A., Briedis V. Topical antifungal bigels: Formulation, characterization and evaluation. Acta Pharm. 2018. 68. P. 223-233. DOI: 10.2478/acph-2018-0014 (Date of access: 01.04.2020).

4. Ляпунов Н. А., Жемерова Е. Г., Безуглая Е. П., Дунай Е. В. Антимикробные консерванты в составе готовых лекарственных средств. Фармация. 2004. Т. 1. С. 13-15.

5. Промышленная фармация. Путь создания продукта: монография / Ж. И. Аладышева и др. Москва, 2019. 394 с.

6. Державна фармакопея України : в 3 т. / ДП «Український науковий фармакопейний центр якості лікарських засобів». 2-е вид. Харків : ДП «Український науковий фармакопейний центр якості лікарських засобів», 2015. Т. 1. 1128 с.

7. Федоровская М. И., Половко Н. П., Куцик Р. В. Изучение эффективности антимикробного консерванта в составе гель-маски с соком крапивы двудомной, предназначенной для применения при телогеновой алопеции. Вестник Таджикского национального университета. Серия естественных наук. 2017. № 1. С. 200-204.

8. Попова Т. В., Кухтенко Г. П., Гладух Є. В. Аналіз консервантів, що застосовуються в технології виробництва м'яких лікарських засобів. Матеріали VII наук.-практ .конф. з міжнар. участю, 27-28 верес. 2018 р. Тернопіль : ТДМУ, 2018. С. 122-123.

\section{REFERENCES}

1. Zuikina, S. S., Vyshnevska, L. I. (2020). Upravlinnia, ekonomika ta zabezpechennia yakosti v farmatsii, 1 (61), 6-13. doi: https://doi.org/10.24959/ uekj.20.10.

2. Immink, J. N., Maris, J. J. E., Crassous, J. J., Stenhammar, O., Schurtenberger, P. (2019). Reversible formation of thermoresponsive binary particle gels with tunable structural and mechanical properties. ACS Nano, 13, 3292-3300. doi: https://doi.org/10.1021/acsnano.8b09139.

3. Mazurkeviciute, A., Ramanauskiene, K., Ivaskiene, K. M., Grigonis, A., Briedis, V. (2018). Topical antifungal bigels: Formulation, characterization and evaluation. Acta Pharm., 68, 223-233. doi: 10.2478/acph-2018-0014.

4. Liapunov, N. A., Zhemerova, E. H., Bezuhlaia, E. P., Dunai, E. V. (2004). Farmatciia, 1, 13-15.

5. Aladysheva, Zh. I. et al. (2019). Promyshlennaia farmatciia. Put sozdaniia produkta. Moscow, 394.

6. DP "Ukrainskyi naukovyi farmakopeinyi tsentr yakosti likarskykh zasobiv". (2015). Derzhavna Farmakopeia Ukrainy. (Vols. 1-3; Vol. 1). (2d ed.). Kharkiv: DP “Ukrainskyi naukovyi farmakopeinyi tsentr yakosti likarskykh zasobiv”, 1128.

7. Fedorovskaia, M. I., Polovko, N. P., Kutcik, R. V. (2017). Vestnik Tadzhikskogo natcionalnogo universiteta. Seriia estestvennykh nauk, 1, 200-204.

8. Popova, T. V., Kukhtenko, H. P., Hladukh, Ye. V. (2018). Analiz konservantiv, shcho zastosovuiutsia v tekhnolohii vyrobnytstva m'iakykh likarskykh zasobiv. Materialy VII nauk.-prakt.konf. z mizhnar. uchastiu (27-28 veres. 2018 r.). (pp. 122-123). Ternopil: TDMU.

\section{Відомості про авторів:}

Зуйкіна С. С., кандидатка фармац. наук, доцентка кафедри аптечної технології ліків, Національний фармацевтичний університет Міністерства охорони здоров'я України. E-mail: zujkin.svetlana@gmail.com. ORCID: http://orcid.org/0000-0002-7546-6062

Вишневська Л. І., докторка фармац. наук, професорка, завідувачка кафедри аптечної технології ліків, Національний фармацевтичний університет Міністерства охорони здоров'я України. E-mail: liliiavyshnevska@gmail.com: ORCID: https://orcid.org/0000-0002-6887-3591 Стрілець О. П., докторка фармац. наук, професорка кафедри біотехнології, Національний фармацевтичний університет Міністерства охорони здоров'я України. E-mail: oksanastr1970@gmail.com. ORCID: https://orcid.org/0000-0003-0846-8663 Information about authors:

Zuikina S., Ph.D in Pharmacy, Associate Professor of Department of Pharmaceutical Technology of Drugs, National University of Pharmacy of the Ministry of Health of Ukraine. E-mail: zujkin.svetlana@gmail.com. ORCID: http://orcid.org/0000-0002-7546-6062

Vyshnevska L., Doctor of Pharmaceutical Sciences, Professor, Head of the Department of Pharmaceutical Technology of Drugs, National University of Pharmacy of the Ministry of Health of Ukraine. E-mail: liliiavyshnevska@gmail.com. ORCID: https://orcid.org/0000-0002-6887-3591 Strilets O., Doctor of Pharmaceutical Sciences, Professor of the Department of Biotechnology, National University of Pharmacy of the Ministry of Health of Ukraine. E-mail: oksanastr1970@gmail.com. ORCID: https://orcid.org/0000-0003-0846-8663.

Сведения об авторах

Зуйкина С. С., кандидат фармац. наук, доцент кафедры аптечной технологии лекарств, Национальный фармацевтический университет Министерства здравоохранения Украины. E-mail: zujkin.svetlana@gmail.com. ORCID: http://orcid.org/0000-0002-7546-6062 Вишневская Л. И., доктор фармац. наук, профессор, заведующая кафедрой аптечной технологии лекарств,

Национальный фармацевтический университет Министерства здравоохранения Украины. E-mail: liliiavyshnevska@gmail.com. ORCID: https://orcid.org/0000-0002-6887-3591

Стрилец О. П., доктор фармац. наук, профессор кафедры биотехнологии, Национальный фармацевтический университет Министерства здравоохранения Украины. E-mail: oksanastr1970@gmail.com. ORCID: https://orcid.org/0000-0003-0846-8663

Надійшла до редакції 06.07.2020 p. 